

\section{KANAL-OPINI FARMASI SOSIAL: \\ CATATAN SISI BARU FARMASI}

Nurul Mardiati

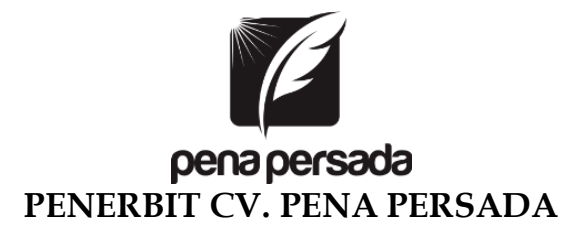




\title{
KANAL-OPINI FARMASI SOSIAL: \\ CATATAN SISI BARU FARMASI
}

\author{
Penulis: \\ Nurul Mardiati \\ ISBN : 978-623-6688-16-8 \\ Cover Design: \\ Retnani Nur Briliant \\ Layout : \\ Nisa Falahia \\ Penerbit CV. Pena Persada \\ Redaksi : \\ Jawa Tengah \\ Email : penerbit.penapersada@gmail.com \\ Website : penapersada.com \\ Phone : (0281) 7771388
}

Jl. Gerilya No. 292 Purwokerto Selatan, Kab. Banyumas

Anggota IKAPI

All right reserved

Cetakan pertama : 2020

Hak Cipta dilindungi oleh undang-undang. Dilarang memperbanyak karya tulis ini dalam bentuk apapun tanpa izin penerbit. 


\section{KATA PENGANTAR}

Puji syukur penulis panjatkan kepada Allah SWT. yang telah melimpahkan segala rahmat dan hidayahNya sehingga penulis berhasil menyelesaikan buku yang berjudul "Kanal-Opini Farmasi Sosial". Buku ini merupakan kumpulan opini penulis di bidang Manajemen Farmasi dan Farmasi sosial dalam rentang waktu 2011-2020, sebagian besar pernah diterbitkan di berbagai media massa. "KanalOpini Farmasi Sosial" mencakup hasil pengamatan, literatur, pendidikan dan bentuk respon penulis atas isu-isu di dunia farmasi baik dalam skala lokal-isu di Wilayah Kalimantan Selatan maupun nasional.

Dalam penulisan buku ini penulis mendapatkan bantuan dan dukungan dari berbagai pihak. Selesainya buku ini juga dimungkinkan karena dorongan dari Suami saya, Helman Rosyadi yang tidak jarang menjadi partner dalam berbagai diskusi termasuk dunia farmasi \& kedua anak kami, Ahmad Mubarak Rosyadi dan Salma Qurrata A'yun Rosyadi. Penulis mengucapkan terimakasih kepada semua pihak yang telah membantu penerbitan buku ini.

Penulis menyadari buku ini masih jauh dari sempurna sehingga penulis mengharapkan saran dan kritik guna penyu-sunan karya berikutnya. Semoga buku ini bermanfaat bagi semua pihak, khususnya masyarakat farmasi di Indonesia.

Banjarbaru, 2021

Penulis

Nurul Mardiati 


\section{TESTIMONI BUKU}

Buku yang menarik untuk disimak sebagai "potret" dunia kefarmasian di Indonesia yang begitu "unik", semoga bisa menjadi pembelajaran bagi Insan Farmasi khususnya Apoteker agar menjadi Apoteker yang berkarakter dan bertanggung jawab dimanapun dia berpraktek.

Apt. Surya Wahyudi, S.Si., MM. Ketua PD IAI Kalsel 20182022

Buku ini sangat menarik untuk dibaca, karena menyampaikan isu-isu terkini terkait apoteker, perannya dalam pelayanan kesehatan dan juga isu global lainya antara lain resistensi antibiotik, regulasi kefarmasian dan juga tantangan serta peluang bisnis industry farmasi. Isu-isu yang diangkat menarik untuk dikaji lebih lanjut dan butuh keseriusan dalam penangananya. Penanganan yang dilakukan tidak lepas dari kooordinasi dan kerjasama antara stake holder, baik apoteker dalam wadah IAI, regulator dalam hal ini pemerintah, Perguruan Tinggi, organisasi tenaga kesehatan lainnya juga masyarakat.

Isu apoteker dalam pelayanan yang no pharmacist no services harus segera direalisasikan, termasuk bagaimana mencegah resistensi antibiotik dalam pelayanan farmasi. Apoteker mestinya tidak memberikan antibiotik tanpa resep dokter, bisa memberikan edukasi dan informasi kepada masyarakat terkait risiko resistensi antibiotik. Apoteker di garda terdepan dalam pelayanan kefar-masian dapat memiliki andil besar dalam memperbaiki perilaku masyarakat terkait penggunaan obat yang rasional, makanan yang sehat dan bebas dari bahan pengawet, pemanis, pewarna buatan. Dalam buku ini disampaikan secara jelas. 
Isu-isu terkait regulasi yang beberapa waktu meresahkan PMK No. 3/2020 juga rancangan Undang-undang Kefarmasian, sangat menarik untuk dibahas dan didiskusikan lebih lanjut agar peran apoteker semakit kuat dari sisi regulasi dan kompetensi serta implementtasinya di masyarakat. Buku ini bisa memantik agar Apoteker dan IAI bersatu dan bersinergi untuk goalnya RUU kefarmasian, sebagai pondasi dalam berkontribusi bagi Negara dalam bidang kesehatan.

Isu lainnya terkait peluang industri farmasi Indonesia, biodiversitas alam Indonesia untuk pengembangan obat alam sangat menarik, ini menjadi semangat bagi masyarakat khususnya apoteker untuk dapat berwirausaha. Akan tetapi kebangkrutan nyonya meneer dapat menjadi pembelajaran bagi kita, ada apa perusahaan nyonya meneer yang demikian lama akhirnya bangkrut, apakah salah di manajemen, dukungan pemerintah kurang atau faktor lain sebagai penyebabnya.

Buku ini sangat bermanfaat untuk pembaca agar dapat bersifat kritis dengan situasi lingkungan yang ada, juga dapat memberikan pemikiran komprehensif dari problem nasional bahkan global, sebagai upaya untuk memperoleh solusi dan untuk selalu bersinergi agar tetap maju serta berkontribusi pada masyarakat dalam bidang kesehatan khususnya kefarmasiaan.

Apt. Dr. Satibi, S.Si., M.Si. Akademisi Fakultas Farmasi Universitas Gadjah Mada

Bagus, layak dibaca.

Apt. Yulianto, M.P.H. (Romo Sukir Satrija Djati)-Medicine and Health Motivator (Akademisi Program Studi Farmasi Universitas Islam Indonesia) 


\section{DINAMIKA APOTEKER DI TENGAH DINAMIKA MASYARAKAT DARI "KACAMATA" SEORANG APOTEKER MUDA}

Apoteker atau farmasis adalah bagian dari masyarakat. Sehingga apapun yang tengah terjadi di masyarakat terutama yang terkait dengan obat maupun sediaan farmasi lainnya tentu tidak akan pernah lepas dari kehidupan seorang apoteker. Dari kacamata seorang apoteker, berbagai peristiwa yang terjadi di tengah masyarakat tersebut ternyata bisa dikupas dari sisi yang berbeda. Inilah yang coba dipotret dari kumpulan tulisan atau opini sejawat Apoteker Nurul Mardiati yang menghiasi halaman berbagai surat kabar ini. Di tengah minimnya publikasi yang dilakukan oleh apoteker, kumpulan tulisan ini seolah oase di tengah padang pasir.

Apoteker yang notabene adalah seseorang yang ahli di bidang obat, tentu opini atau pendapatnya tentang berbagai hal terutama yang terkait dengan obat maupun sediaan farmasi lainnya sangat ditunggu oleh masyarakat. Namun sayangnya masih sangat jarang sekali apoteker yang "mau" dan "berani" menuliskan opininya kepada publik. Padahal di tengah serbuan informasi yang sangat masif lewat berbagai media sosial, masyarakat tentu sangat membutuhkan opini/pendapat seseorang yang memang ahli di bidang obat-obatan ini. Padahal sejak bangku kuliah kita secara tidak langsung telah diajarkan untuk mengamati dan menuliskan berbagai macam peristiwa yang terjadi di sekitar kita. Untuk itulah saya sangat senang sekali dengan penerbitan buku ini, yang merupakan kumpulan tulisan dari sejawat apoteker yang mencoba memotret dinamika kehidupan masyarakat terutama yang terkait dengan obat dan sediaan farmasi lainnya. 
Semoga buku ini bisa menjadi inspirasi bagi teman-teman sejawat lainnya untuk "mau" dan "berani" menuliskan opininya dan memberikan pencerahan kepada masyarakat di tengah derasnya berbagai macam informasi yang tidak sepenuhnya bisa dipertanggung jawabkan.

Apt. Drs. Bambang Priyambodo (General ManagerManufacture PT. Jamu Air Mancur)

Sebuah peristiwa akan menjadi abadi dalam lembaran sejarah jika dibuat dalam karya berupa tulisan. Sebuah upaya yang sangat patut di apresiasi atas terbitnya buku yang memuat tulisan tentang peristiwa-peristiwa penting yang secara langsung atau tidak langsung semestinya memberikan perubahan pada Profesi Kefarmasian di Indonesia. Harapan besar bagi dunia kefarmasian khususnya di Banua sumbangsih pemikiran berupa tulisan seperti ini dapat berperan membangun cara berfikir dan budaya baru bagi Farmasis di Indonesia, sekaligus menjadi penanda lahirnya Farmasis sekaligus Negarawan yang tidak hanya cerdas secara sains tapi juga cerdas dari sisi sosial.

Apt. Hasan Ismail, S.Farm., MM -Anggota Presidium Nasional FIB 


\section{DAFTAR ISI}

KATA PENGANTAR ....................................................... ii

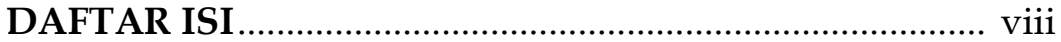

TESTIMONI BUKU ...................................................... iv

1. "Benang Kusut" Profesi Apoteker di Indonesia......... 1

2. Resistensi Antibiotik: Manusia di Bumi Sedang "Terancam" ..................................................................... 6

3. Embrio Perusahaan Besar Herbal itu di Banjarmasin (Refleksi Generasi Muda Farmasis Asli Banua) ......... 11

4. Museumkan Resep Cakar Ayam Pak Dokter ............. 15

5. Salah Persepsi Obat Generik ....................................... 18

6. Polemik Draft Permenkes Praktek Dokter Mandiri... 23

7. Vaksin Palsu dan Apotek Rakyat................................ 28

8. Apoteker di Garda Terdepan........................................ 32

9. Sinergi Awasi Jajanan Anak Sekolah ........................... 39

10.Perang Melawan Zenith di Kalsel ................................ 42

11.Drama Panjang Pailitnya Nyonya Meneer.................. 46

12. Babak Baru Revousi Dunia Farmasi Di Indonesia ..... 50

13.Farmasis Kecewa, Pray For Farmasis ......................... 54

14.Kontroversi Klaim Produk Bio Nuswa untuk

Penyembuhan COVID-19........................................... 56

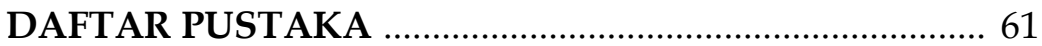

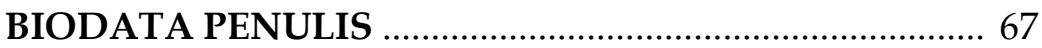




\section{"BENANG KUSUT" PROFESI APOTEKER DI INDONESIA}

Dunia kefarmasian dari zaman ke zaman telah mengalami berbagai perubahan. Secara historis setidaknya dunia kefarmasian telah melalui empat periode. Pertama, periode tradisional (sebelum 1960-an). Dalam periode ini, fungsi apoteker hanyalah terbatas pada menyediakan, membuat, dan mendistribusikan produk yang berkhasiat obat. Fungsi tersebut dilaksanakan dengan melibatkan seni dan ilmu pembuatan bahan obat yang bersumber dari bahan alam atau sintetik menjadi sediaan atau produk yang sesuai untuk digunakan dalam mencegah, mendiagnosa, atau mengobati penyakit. Periode ini mulai goyah ketika pembuatan sediaan obat secara bertahap mulai dikerjakan oleh indutri farmasi. Peran seorang apoteker pada era ini mulai menyempit.

Kedua, periode transisional (tahun 1960-an /1970-an). Salah satu kecenderungan pada periode ini adalah adanya perkem-bangan ilmu kedokteran yang makin spesialistis. Kemajuan dalam ilmu kedokteran yang pesat khususnya farmakologi dan banyaknya obat yang mulai membanjiri dunia kesehatan menyebabkan para dokter merasa ketinggalan dalam ilmunya. Selain itu kemajuan dalam ilmu diagnosa, alat-alat diagnosa, serta penyakit-penyakit yang baru muncul dirasa membingungkan para dokter. Satu profesi dirasa tidak dapat lagi menangani semua pengetahuan yang berkembang sedemikian pesat. Peran apoteker secara lebih mulai banyak dibutuhkan oleh masyarakat. Seiring dengan kecenderungan tersebut tuntutan masya- 
rakat untuk pelayanan media dan farmasi yang berkualitas disertai tuntutan pertang-gungjawaban peran serta para dokter dan apoteker.

Ketiga, periode masa kini (farmasi klinis). Praktik kefarmasian pada periode ini berorientasi pelayanan kepada pasien lebih dari orientasi semata-mata kepada produk (obat). Pemaknaan praktik kefarmasian pada periode ini adalah penerapan pengetahuan dan keahlian farmasi dalam membantu memaksimalkan efek obat dan meminimalkan toksisitas bagi pasien secara individual.

Keempat, era sekarang yaitu periode pharmaceutical care. Periode ini di Indonesia sendiri masih dikatakan dalam tahap perkembangan. Pelayanan kefarmasian (pharmaceutical care) merupakan bentuk pelayanan dan tanggung jawab langsung profesi apoteker dalam pekerjaan kefarmasian untuk mening-katkan kualitas hidup pasien. Dibandingkan dengan periode farmasi klinis, periode ini lebih 'kuat' orientasinya kepada pasien. Pelayanan kefarmasian ini mengarahkan tentang kebiasaan atau pola hidup yang mendukung tercapainya keberhasilan pengo-batan, memberi informasi tentang program pengobatan yang harus dijalani pasien, memonitor hasil pengobatan dan bekerja sama dengan profesi lainnya untuk mencapai kualitas hidup yang optimal bagi pasien.

Konsekuensi perubahan orientasi tersebut, apoteker tentulah dituntut untuk meningkatkan pengetahuan, ketrampilan, dan perilaku untuk dapat melaksanakan interaksi langsung dengan pasien. Konsekuensi perubahan orientasi itu sendiri, terutama pelaksanaannya di apotek secara tanggap direspon oleh Direktorat Jenderal Pelayanan Kefarmasian dan Alat Kesehatan, Kementerian Kesehatan Republik Indonesia serta (IAI) Apoteker Indonesia sendiri dalam bentuk Keputusan Menteri Kesehatan Republik 
Indonesia Nomor 1027/MENKES/IX/2004 tentang Standar Pelayanan Kefarmasian di Apotek yang merupakan dasar dalam penyelenggaraan pelayanan apotek. Keputusan menteri tersebut menetapkan bahwa semua tenaga kefarmasian baik itu apoteker maupun tenaga teknis kefarmasian dalam melaksanakan tugas profesinya di apotek agar mengacu pada standar tersebut.

Sementara itu, pelayanan kefarmasian selama ini dinilai oleh banyak pengamat masih berada dibawah standar. Ilham Kuncahyo, seorang pengajar di Fakultas Farmasi Universitas Setia Budi Surakarta di Indonesia, menyatakan bahwa apoteker sebagai peran sentral dan bertanggung jawab penuh dalam memberikan informasi obat kepada masyarakat belum melaksanakan dengan baik, bahkan dapat disebut kesenjangan ini terlalu lebar. Fenomena yang sama mungkin akan kita temukan pula di apotek-apotek wilayah kota Banjarmasin yang berdasarkan data Dinas Kesehatan Kota Banjarmasin per Desember 2010 saja telah mencapai 119 apotek. Hal yang kemudian menjadi pertanyaan besar adalah jika pada kenyataannya interaksi antara apoteker dan pasien masih nol besar, sejauh apa peran dan tanggung jawab profesi apoteker di apotek yang idealnya mengacu pada standar tersebut dilaksanakan dengan baik. Jangankan bicara interaksi apoteker dengan pasien dalam memberikan pelayanan terbaik, intensitas kehadiran apoteker di apotek saja masih dipertanyakan.

Dalam perkara tersebut di atas, apoteker yang kurang profesional dalam pelaksanaan tugas dan wewenangnya sendiri tidak dapat sepenuhnya dipersalahkan. Salah satu faktor penyebabnya, barang kali adalah apoteker yang merasa hanya sebagai penanggung jawab semata dan 'sialnya' lagi tanggung jawab itupun hanya dimaknai sebagai peran dan tanggung jawab dalam bidang 
administrasi semisal membuat laporan pemakaian obat golongan narkotika dan psikotropika ke pihak Pemeriksa Obat dan Makanan (BPOM) setempat serta Dinas Kesehatan Provinsi dan Kota. Padahal peran dan tanggung jawab apoteker lebih dari sekedar itu, antara lain juga memenuhi tugas di bidang pengabdian profesi dan komersiil.

Apoteker yang merasa hanya sebagai penanggung jawab tersebut biasanya hanya menjadikan bekerja di apotek sebagai pekerjaan sambilan. Akibatnya bisa dipastikan waktu kerja yang diinterpretasikan dari intesitas para apoteker berada di apotek sangatlah minim, mereka cenderung lebih fokus kepada pekerjaan pokoknya. Bekerja di apotek tidak lebih dari sisa waktu melaksanakan kewajiban-kewajiban di pekerjaan pokok. Lagi-lagi dalam posisi inipun apoteker tidak dapat sepenuhnya dipersalahkan. Alasan para apoteker tersebut sangatlah manusiawi adanya, salah satunya karena gaji bekerja di apotek dirasa belum mampu memenuhi kebutuhan hidup mereka. Apalagi jika nominal gaji tersebut dibandingkan ketika apoteker berperan secara optimal di apotek. Terkait hal ini, para apoteker juga diketahui memiliki jam kerja yang panjang (baca: apotek biasanya memberikan pelayanan kepada masyarakat dari pagi hingga menjelang malam). Dilematis memang!

Dilematis ini pula yang kiranya 'terbaca' oleh para pengurus daerah IAI di Yogyakarta. Dalam keterbacaan dilematis profesi apoteker di daerahnya tersebut, IAI di Yogyakarta beberapa waktu lalu menerbitkan Surat Keputusan Pengurus Daerah IAI D.I Yogyakarta nomor : 015/IAI-DIY/SK/II/2010 tentang Standar Jasa Profesi Apoteker D.I. Yogyakarta. Dalam surat keputusan tersebut tertuang jasa profesi minimal baik bagi apoteker yang statusnya sebagai Apoteker Pengelola Apotek maupun 
Apoteker Pendamping (baca: apoteker pengganti bila apoteker pengelola apotek tidak berada di apotek) serta bagi hasil antara apoteker dan Pemilik Sarana Apotek. Naif rasanya jika memungkiri hal ini merupakan angin surga tersendiri bagi para apoteker di daerah Yogjakarta. Sementara itu, pengurus daerah IAI Kalimantan Selatan sendiri termasuk daerah-daerah lain di Indonesia sepengetahuan saya belum menerapkan hal yang serupa.

Dibandingkan penilaian standar jasa profesi dalam besarnya nominal tersebut, saya lebih tertarik untuk memaknai kebijakan IAI di Jogjakarta sebagai bentuk penghargaan yang layak bagi para apoteker untuk lebih mengoptimalkan diri dalam melaksanakan peran dan tanggung jawabnya, terlebih goal besarnya toh nantinya untuk peningkatan kualitas hidup pasien. Bukankah begitu! Bagaimana menurut anda?

*Banjarmasin, 09 Januari 2011* 


\section{RESISTENSI ANTIBIOTIK: MANUSIA DI BUMI SEDANG "TERANCAM"}

Sepanjang sejarah, rasanya tepat menyebut antibiotik sebagai salah satu obat yang populer di kalangan masyrakat. Tak sekedar populer dibandingkan obat golongan lainnya, antibiotik dalam penggunaannya juga senantiasa mendapatkan perhatian yang lebih. Hal ini pula yang kiranya melatarbelakangi Kementerian Kesehatan Republik Indonesia beberapa waktu lalu dalam peringatan Hari Kesehatan Sedunia Ke-60 mengusung tema "Antimicribial Resistance and It's Global Spread". Salah satunya juga sebagai media untuk menyosialisasikan penggunaan antibiotik secara tepat penggunaan antibiotik secara tepat untuk mencegah kekebalan kuman. Diangkatnya tema irasionalitas pemakaian antibiotik tersebut tentulah indikasi tersendiri bahwasanya hal ini merupakan masalah yang teramat penting, menyangkut hajat hidup manusia sedunia kalau boleh saya bilang.

Masa pra antibiotik menempatkan penyakit infeksi sebagai penyakit tanpa sebuah peluang kesembuhan bahkan sangat mematikan. Konon, pada zaman dahulu pernah terjadi wabah penyakit infeksi yang menyebabkan kematian pada seperlima dari populasi manusia di bumi karena sifat penyakit infeksi yang dapat menular melalui berbagai cara. Bahkan karena dahsyatnya, penyakit infeksi sering diidentikkan dengan penyakit kutukan.

Sejarah mencatat nama dr. Alexander Fleming (Inggris, 1928) sebagai penemu pertama kalinya antibiotik yaitu penisilin. Penemuan penisilin ini tidak dapat dipungkiri 
sebagai penemuan yang sangatlah menggembirakan bagi perkembangan dunia kesehatan. Sejarah pengendalian infeksi juga mencatat tahun 1950-an hingga 1980-an sebagai era infeksi mampu diatasi secara baik. Di era tersebut berbagai jenis antibiotik banyak ditemukan dan dikembangkan. Pengembangan obat-obat antibiotik tentulah suatu tonggak utama tersendiri dalam dunia kesehatan. Sayangnya era keemasan penemuan antibiotik tersebut, di atas era 1980-an (baca: belakangan hingga era kini) dicatat sejarah sebagai masa yang kurang menggem-birakan bagi perkembangan antibiotik bahkan dapat dikatakan mengkhawatirkan.

Salah satu hal yang menyebabkan hilangnya era keemasan antibiotik adalah 'trade mark' penggunaan antibiotik sendiri yang secara tidak bijaksana. Antibiotik percaya atau tidak meski berlabel $\mathrm{K}$ dalam lingkaran berwarna merah sangatlah mudah didapatkan, tidak hanya di rumah sakit, puskesmas, dan apotek melainkan juga di toko obat bahkan toko-toko kecil (baca: semacam apotek kelas kelontong) di pasar-pasar. Padahal penandaan label K dalam lingkaran merah tersebut menunjukkan bahwasanya antibiotik tidak boleh diberikan tanpa resep dokter dan hanya dapat diserahkan di apotek, RS, atau puskesmas. Hal ini juga diperparah anggapan awam bahwasanya antibiotik adalah 'obat dewa', seolah-olah antibiotik itu penyembuh segala macam penyakit. Batuk, minta antibiotik. Flu (baca: kasus flu karena virus), minta antibiotik. Masuk angin, minta antibiotik. Bahkan pernah suatu waktu saat pelaksanaan tugas seorang tenaga teknis kefarmasian, pasiennya mengeluh mata kaburpun minta antibiotik. Padahal kondisi-kondisi tersebut diatas sebenarnya tentulah tidak memerlukan terapi antibiotik. 
Penggunaan antibitotik secara tidak bijaksana menimbulkan berbagai dampak negatif, salah satunya adalah timbulnya resistensi. Diksi sederhana dari resistensi adalah kuman menjadi kebal terhadap antibiotik tertentu. Akibatnya, seseorang memerlukan antibiotik dengan dosis yang lebih tinggi atau/ dengan antibiotik lain dengan jenis yang lebih kuat. Menurut Guru Besar Farmakologi Univeristas Gadjah Mada Iwan Dwi Prahasto, resistensi antibiotik menimbulkan masalah kekebalan kuman yang serius. Bakteri mampu bermutasi sehingga tahan terhadap antibiotik. Resistensi ini akan memunculkan wabah superbug, yaitu kondisi dimana bakteri tidak dapat dibunuh oleh antibiotik paling mutakhir sekalipun.

Sementara itu, masalah resistensi antibiotik seolah diperparah oleh hilangnya era keemasan penemuan antibiotik. Belum banyak lagi penemuan jenis-jenis antibiotik baru. Lagi-lagi, seolah memperparah keadaan dana riset penemuan antibiotikpun semakin terbatas. Kenyataan ini seolah menempatkan penggunaan antibiotik secara tidak bijaksana menjadi masalah bak gunung es. Olehnya manusia di bumi sedang 'terancam'. Mengulang wabah penyakit infeksi yang menyebabkan kematian pada seperlima dari populasi manusia di bumi tentulah mimpi buruk.

Salah satu pilihan menyikapi persoalan tersebut adalah bagaimana upaya peningkatan rasionalitas penggunaan antibiotik. Upaya tersebut tentulah melibatkan seluruh elemen di dunia kesehatan, baik itu dokter, perawat, bidan, apoteker maupun masyarakat sendiri. Dokter, perawat, dan bidan wajib bersinergi untuk menghindari hal-hal yang menyebabkan irasionalitas penggunaan antibiotik. Pertama, penggunaan antibiotik pada kondisi-kondisi yang tidak memerlukan terapi antibiotik misalnya pada kasus infeksi 
virus saluran pernafasan atas dan diare akut non spesifik. Kedua, penggunaan satu jenis antibiotik tanpa mengetahui secara jelas infeksi dan kuman penyebabnya. Ketiga, pemberian antibiotik dengan dosis yang tidak mencukupi; misalnya pemberian antibiotik selama tiga hari tanpa memonitor efek terapi yang terjadi. Keempat, pemberian antibiotik secara berlebihan kasus-kasus infeksi non bakterial ringan dengan alasan untuk mencegah komplikasi.

Apoteker sebagai 'dewa' di dunia kefarmasian, salah satunya juga harus berperan aktif dalam memberikan informasi obat; tidak terkecuali obat golongan antibiotik. Apoteker perlu untuk meningkatkan peranannya serta mengurangi pendelegasian tugas dan perannya kepada tenaga teknis kefarmasian. Betapapun, apoteker dan tenaga teknis kefarmasian tentulah berbeda kompetensinya. Terkait hal tersebut, dalam Undang-Undang Republik Indonesia Nomor 36 Tahun 2009 tentang kesehatan pasal 108 ayat 1 sendiri telah disebutkan bahwasanya praktik kefarmasiaan yang meliputi pembuatan termasuk pengendalian mutu sediaan farmasi, pengamanan, pengadaan, penyimpanan dan pendistribusian obat, pelayanan obat atas resep dokter, pelayanan informasi obat serta pengembangan obat, bahan obat dan obat tradisional harus dilakukan oleh tenaga kesehatan yang mempunyai keahlian dan kewenangan sesuai dengan ketentuan peraturan perundang-undangan. Apoteker berkewajiban memberikan informasi obat yang lebih baik pada pasien sehingga nantinya menggugah minat partisipasi aktif pasien yang bahkan dinilai beberapa ahli sebagai upaya mempercepat penyembuhan.

Adapun masyarakat sendiri, hendaknya perlu bersikap kritis terhadap pengobatan yang dijalaninya. Perlu dan hak bagi masyarakat selaku pasien untuk mengetahui segala hal bahkan tentang obat yang diterima; perihal 
kandungan aktif, cara dan rute pemakaian, efek samping, kontraindikasi, bahkanpun toksisitas dan cara kerjanya di dalam tubuh. Karena rasionalitas penggunaan antibiotik itu tanggung jawab kita bersama. Sekali lagi, karena manusia di bumi sedang 'terancam'.

*Yogyakarta, 11 Februari 2012* 


\section{EMBRIO PERUSAHAAN BESAR HERBAL ITU PERNAH ADA DI BANJARMASIN (REFLEKSI GENERASI MUDA FARMASIS ASLI BANUA)}

Wes... Ewes... Ewes... Bablas Angine!, demikian jargon salah satu produk perusahaan herbal terbesar di Indonesia. Sebagian besar masyarakat kita tentu familiar dengan jargon tersebut, familiarpun dengan catatan sejarah ternyata perusahaan besar herbal tersebut berawal di Banua? Saya rasa belum. Ya... saya pikir tidak banyak orang Banua sendiri sekalipun yang tahu bahwasanya sukses perusahaan besar herbal satu itu berawal di Banua kita, BanjarmasinKalimantan Selatan.

Sebagaimana yang saya lansir dari web resmi perusahaan tersebut, sejarah mencatat tahun 1976-1986 sebagai awal dari kisah suksesnya. Sebuah kisah sukses perusahaan herbal yang kini tak hanya punya pasar nasional; tetapi juga telah merambah ke pasar internasional seperti, Malaysia, Arab Saudi, Amerika Serikat, Hongkong, dan Brunei Darussalam. Bermula dari industri obat tradisional di Banjarmasin dalam skala home industry yang waktu itu mulai membuat jamu dari ramuan tumbuhtumbuhan alami. Diantaranya adalah strongpa dan virgitab yang dipasarkan dalam bentuk kapsul.

Jauh sebelum tahun 1976, para jurnalis tempo di eranya pada edisi 13 April 1974 punya kisah panjang sendiri soal ini. Berawal dari ide brilian seorang entrepreneur bernama Kolonel Rahmatullah yang kala itu sehari-hari sebagai asisten I Kodam X Lambung Mangkurat yang juga merupakan mantan Ketua DPRD era tahun 1980-an inilah semua kisah sukses tersebut dimulai. 
Sebuah ide brilian Kolonel Rahmatullah untuk menyarankan Sang keponakan, Muhammad Thoyib yang telah memiliki ijazah Asisten Apoteker-sekalipun gagal melanjutkan studi di Fakultas Farmasi, Universitas Gadjah Mada, Daerah Istimewa Yogjakarta untuk melakukan penelitian bahan obat sejenis akar Pasak Bumi dan serbuk daun Tabat Barito yang berdasarkan 'kisah lama' berabadabad lalu dipercaya memiliki banyak khasiat.

Duet keduanya akhirnya berhasil mendirikan industri obat dari bahan alam tersebut meski baru dalam skala home industry. Bahkan, inspeksi dari Dinas Kesehatan Provinsi Kalimantan Selatan kala itu seolah menjadi angin segar tersendiri yang menghantarkan home industry tersebut berubah menjadi perusahaan dengan nama CV Lorina. Dalam perjalanannya, sayang tidak berapa lama perusahaan ini usahanya macet. Akan tetapi berkat kucuran modal dari investor sekaligus izin Direktorat Jenderal Farmasi Departemen Kesehatan kala itu, CV Lorina justru berkembang dan mendirikan perusahaan yang notabene merupa-kan industri farmasi pertama di Banjarmasin.

Nama perusahaan sendiri diambil dari nama latin terakhir tanaman Tabat Barito yaitu Ficus Deltoida. Strongpa dan Virgitab yang dipasarkan dalam bentuk kapsul tahun 1971 selanjutnya didaftar ujikan ke Lembaga Farmasi Nasional Jakarta era sekarang sejenis pemegang regulasi kerja sama antara Kementerian Kesehatan dan Badan Pemeriksa Obat \& Makanan. Hasilnya, Strongpa dan Virgitab dinyatakan berkhasiat dan tidak berbahaya bagi kesehatan. Bahkan ditahun yang sama keduanya sempat pula dikampanyekan di Jakarta Fair.

Modal atas swadaya sendiri yang mencapai Rp. 10.000.000,00 kala itu menghantarkan- meski berdasarkan susunan direksi perusahaan tersebut diketahui ditopang 
oleh para investor non pribumi; seperti Gunawan Wanujaya sebagai Dirut, Harman Mulyadi dan Johan Mulyadi bersaudara masing-masing sebagai Direksi dan Kuasa Direksi - perusahaan sejak Februari 1974 produksinya menembus angka 30.000 kapsul/bulan. Sebagaimana yang saya paparkan sebelumnya, perusahaan tersebut sekarang tumbuh dan telah sedemikian berkembang -meski tidak lagi di Banjarmasin, karena perusahaan sejak 1987 berpindah ke Nambangan, Wonogiri, Jawa Tengah tidak hanya untuk memenuhi permintaan pasar industri herbal di Indonesia melainkan juga mancanegara. Dalam melaksanakan proses produksi, perusahaan tersebut menggunakan standar GMP (Good Manufacturing Process) Eropa, GMP Indonesia (Cara Pembuatan Obat Tradisional yang Baik), dan FDA (Food and Drug Adminis-tration).

Bukan lantas dongeng menyebut embrio perusahaan besar herbal itu di Banjarmasin-Kalimantan Selatan. Indonesia dengan keanekaragaman hayati yang menduduki urutan kedua di dunia setelah Brasil, sebagian besarnya di Kalimantan. Studi terhadap bahan obat di Kalimantan yang dikenal sebagai daerah tropis banyak menyimpan potensi sebagai bahan obat sekurang-kurangnya 4.000 spesies tumbuhan yang menjadi sumber temuan obat baru. Sementara itu Indonesia berdasarkan data tahun 2009 saja mencatat nilai pasar obat tradisional Indonesia mencapai US\$ 1 Milyar, suatu angka yang tidak bisa dibilang kecil dalam usahan pemanfaatan sumber daya alam bahan obat. Menurut WHO, Badan Kesehatan Dunia hingga 65\% dari penduduk negara maju dan $80 \%$ dari penduduk negara berkembang telah menggunakan obat herbal.

Berangkat dari fakta historis bahwasanya Bumi Lambung Mangkurat pernah menjadi embrio industri farmasi besar di Indonesia, ditambah semakin banyaknya 
generasi muda farmasis profesional-salah satunya nanti diharapkan dalam pengelolaan obat dan bahan obat, khususnya dalam upaya eksplorasi bahan-bahan alam- asli banua baik itu yang memang dicetak Universitas Lambung Mangkurat sebagai satu-satunya pendidikan tinggi strata-1 penyelenggara Program Studi Farmasi di Kalimantan Selatan maupun Perguruan Tinggi Negeri serta Perguruan Tinggi Swasta lainnya kiranya bukan utopia berharap Kalimantan Selatan kelak suatu hari mampu menjadi stake holder perkembangan obat bahan alam Indonesia, khususnya Kalimantan. Antara sebuah tantangan dan peluang bagi generasi muda farmasis asli Banua. Kitakah salah satu bagian stake holder-nya?

*Yogyakarta, 1 Maret 2012* 